\title{
Seasonal variation in mortality of brown trout (Salmo trutta) in an acidic aluminium-rich lake
}

\author{
Espen LYDERSEN, Nina W.A. RUKKE ${ }^{1)}$, Jannike G.B. JENSEN ${ }^{2)}$, Birgitte M. KJELSBERG ${ }^{1)}$, Bente TORNSJ $\varnothing^{2)}$, \\ Rolf D. VOGT ${ }^{2)}$, L. Asbjørn VØLLESTAD ${ }^{1)}$ and Antonio B.S. POLÉO ${ }^{1) *}$
}

Norwegian Institute for Water Research, P.O. Box 173, Kjelsås, N-0411, Oslo, Norway.

${ }^{1)}$ Department of Biology, University of Oslo, P.O. Box 1066, Blindern, N-0316, Oslo, Norway

${ }^{2)}$ Department of Chemistry, University of Oslo, P.O. Box 1033, Blindern, N-0315, Oslo, Norway

*e-mail corresponding author: toni.poleo@bio.uio.no

\begin{abstract}
We have studied the seasonal variation in aluminium toxicity in caged brown trout (Salmo trutta), during one year (October 1994 to September 1995) in a small acidic aluminium rich lake, Lake Nepptjern (ANC-22.6 $\mu$ eq $l^{-1}, p H 5.2$, total Al $400 \mu \mathrm{g} l^{-1}$ ). Trout from two and three different year classes were exposed each month to the lake water for $48 \mathrm{~h}$. Fish were placed in keepnets located in the middle of the lake, at $2 \mathrm{~m}$ depth. Fish mortality and water physico-chemistry were monitored during the exposures. The concentration of inorganic monomeric aluminium in the water was approximately $300 \mu \mathrm{g} l^{-1}$ in average, and the water was acutely toxic to the fish. The observed mortality varied throughout the year, and was highest during spring and summer. During spring, the small fish were more sensitive to the toxic water than larger fish, while the opposite was the case during summer. Water temperature and fish length could explain most of the seasonal variation in mortality. Statistical analyses indicated that water acid neutralising capacity (ANC) and the amounts of total organic carbon (TOC) and silicon in the water also could explain some of the variation in mortality. Variation in other physico-chemical parameters, however, such as silicon, TOC and ANC could only explain the variation in mortality to a limited extent. The mechanism for the temperature dependent mortality is discussed, and we suggest that the dependence of water $\mathrm{O}_{2}$-solubility and fish metabolism upon temperature is of importance. The difference in mortality between small and large fish is discussed in terms of the gill area/body weight ratio, and it seems to be that small fish suffer more from diffusive ion loss having a larger relative gill area than larger fish. Large fish, on the other hand, have a lower relative maximum oxygen uptake than small fish and will suffer more under conditions where aluminium is accumulated on the gill surface.
\end{abstract}

Key words: acidification, seasonal variation, Al-toxicity, brown trout, mortality

\section{INTRODUCTION}

Soil acidification increases the mobilisation of aluminium to surface waters (Cronan \& Schofield 1979, Driscoll \& Postek 1996). Increased concentrations of aqueous aluminium are considered the major environmental problem due to freshwater acidification, and the relationship between aqueous aluminium and fish toxicity is well documented (Driscoll et al. 1980; Sparling \& Lowe 1996; Gensemer \& Playle 1999). Dissolved in water, aluminium occurs on many different physicochemical forms with varying toxicity to aquatic organisms (Gensemer \& Playle 1999). Inorganic monomeric aluminium species has been considered the most toxic aluminium forms. Several studies, however, have shown that aluminium toxicity is correlated to changes in water physico-chemical conditions, rather than the occurrence of a certain toxic aluminium species (Dickson 1978; Driscoll et al. 1980; Grahn 1980; Baker \& Schofield 1982; Gensemer \& Playle 1999). Water pH, temperature, dissolved organic carbon, and silicon are among the factors modifying aluminium toxicity directly by influencing aluminium chemistry (Driscoll et al. 1980; Birchall et al. 1989; Poléo et al. 1991). Calcium is also important for the aluminium toxicity in fish, but the cal- cium ions seem to alter the toxicity indirectly mainly by influencing gill permeability properties (McDonald 1983; Wood \& McDonald 1987). Since all these factors change during the year, we predict that the aluminium toxicity will also be variable.

We have studied aluminium toxicity in caged brown trout (Salmo trutta) during one year in a small acidic aluminium rich lake $\left(\mathrm{pH} \mathrm{5.2,} \mathrm{total} \mathrm{Al} 400 \mu \mathrm{g}^{-1}\right)$. The purpose of this study was to evaluate relationships between seasonal variation in physico-chemical conditions and aluminium toxicity. The aim was to identify principal chemical and biological factors explaining the seasonal variation in toxicity.

\section{METHODS}

\subsection{Site description}

Lake Nepptjern is located $398 \mathrm{~m}$ above sea level, outside Oslo, Norway. It is a small lake $\left(8600 \mathrm{~m}^{2}, 8.5 \mathrm{~m}\right.$ mean depth) with a catchment area of $0.28 \mathrm{~km}^{2}$. The mean residence time of the lake water is 3 months. The lake is relatively well protected against wind, and the duration of ice cover is normally from October/November until middle of May. During the monitoring year, the lake circulated only during the fall. A 
Tab. 1. Length and weight (mean \pm s.d.) of the three year classes of fish used in the experiments.

\begin{tabular}{|c|c|c|c|c|c|c|c|c|c|}
\hline & \multicolumn{3}{|c|}{1993} & \multicolumn{3}{|c|}{1994} & \multicolumn{3}{|c|}{1995} \\
\hline & $\begin{array}{l}\text { length } \\
(\mathrm{cm})\end{array}$ & $\begin{array}{l}\text { weight } \\
(\mathrm{g})\end{array}$ & $\mathrm{n}$ & $\begin{array}{l}\text { length } \\
(\mathrm{cm})\end{array}$ & $\begin{array}{l}\text { weight } \\
(\mathrm{g})\end{array}$ & $\mathrm{n}$ & $\begin{array}{l}\text { length } \\
(\mathrm{cm})\end{array}$ & $\begin{array}{c}\text { weight } \\
(\mathrm{g})\end{array}$ & $\mathrm{n}$ \\
\hline Oct 29,94 & $10.7 \pm 1.0$ & $13.3 \pm 3.8$ & (31) & $6.4 \pm 0.6$ & $3.0 \pm 1.0$ & (37) & & & \\
\hline Dec 6, 94 & $11.5 \pm 1.3$ & $17.3 \pm 6.3$ & (31) & $6.1 \pm 0.7$ & $2.7 \pm 0.9$ & (31) & & & \\
\hline $\operatorname{Jan} 6,95$ & $11.2 \pm 1.1$ & $16.1 \pm 4.3$ & (29) & $6.1 \pm 0.9$ & $3.0 \pm 1.3$ & (30) & & & \\
\hline Feb 10,95 & $12.4 \pm 1.2$ & $19.9 \pm 6.0$ & (35) & $6.6 \pm 0.7$ & $2.9 \pm 0.8$ & (30) & & & \\
\hline Mar 3, 95 & $11.9 \pm 0.9$ & $21.5 \pm 5.7$ & (28) & $6.1 \pm 0.6$ & $2.6 \pm 0.8$ & (31) & & & \\
\hline Apr 2, 95 & $11.1 \pm 1.1$ & $13.8 \pm 4.0$ & (32) & $7.0 \pm 0.8$ & $3.4 \pm 1.3$ & (32) & & & \\
\hline Apr 22, 95 & $11.5 \pm 0.9$ & $17.1 \pm 4.4$ & (32) & $6.6 \pm 0.7$ & $3.5 \pm 1.3$ & (31) & & & \\
\hline May 30, 95 & $10.7 \pm 1.0$ & $13.5 \pm 3.7$ & (31) & $6.6 \pm 0.7$ & $3.5 \pm 1.3$ & (31) & & & \\
\hline Jul 8, 95 & $12.4 \pm 1.5$ & $23 \pm 8$ & (30) & $8.5 \pm 0.9$ & $7.4 \pm 2.3$ & (32) & $3.2 \pm 0.3$ & $0.3 \pm 0.1$ & (32) \\
\hline Aug 3,95 & $15.6 \pm 3.5$ & $47 \pm 21$ & (29) & $10.2 \pm 1.0$ & $12.4 \pm 3.5$ & (34) & $4.5 \pm 0.4$ & $0.9 \pm 0.3$ & (30) \\
\hline Aug 31,95 & $18.9 \pm 2.2$ & $90 \pm 32$ & (31) & $11.1 \pm 1.3$ & $17.9 \pm 6.6$ & (30) & $4.7 \pm 0.4$ & $1.2 \pm 0.4$ & (31) \\
\hline Sep 28,95 & $17.4 \pm 1.6$ & $65 \pm 17$ & (31) & $11.3 \pm 1.2$ & $17.3 \pm 5.9$ & (30) & $5.4 \pm 0.6$ & $1.6 \pm 0.7$ & (31) \\
\hline
\end{tabular}

complete circulation during spring is probably uncommon for this lake, because ice-off takes place relatively late in the spring. Because the irradiation is high at that time, the lake stratifies very quickly after ice-off. The predominant vegetation in the catchment area is heather species and Norwegian spruce (Pícea abies). The spruce covers about $70 \%$ of the catchment area. The lake is surrounded by Sphagnum mosses. Despite this vegetation, the lake is a clear water lake with a mean concentration of total organic carbon (TOC) of $1.9 \mathrm{mg} \mathrm{l}^{-1}$. Secchi-depth down to $15 \mathrm{~m}$ has been recorded, which is also the maximum depth of the lake.

Based on a Norwegian lake survey (Henriksen \& Andersen 1992), Lake Nepptjern is probably the most toxic lake within the geographic area. This is primarily due to its high concentration of inorganic monomeric aluminium $\left(300 \mu \mathrm{g} \mathrm{l}^{-1}\right)$. The high aluminium concentration, as well as the relative low $\mathrm{pH}(5.0)$, is due to a combination of relatively high inputs of acid compounds from precipitation and low $\mathrm{pH}$-buffering capacity within the catchment. A screening of a large array of other metals showed that only aluminium is elevated in this lake (data not shown). The lake hosts no fish, and lost its perch (Perca fluviatilis) population many decades ago (Grande 1970).

\subsection{Experimental animals}

Brown trout from the Lake Tunhovd strain, were obtained from a hatchery nearby Oslo. The fish were first generation hatchery fish, and we used fish from three different year classes (Tab. 1). The fish were transported to Lake Nepptjern in closed aerated plastic bags. The transport time from the hatchery until the fish was placed in keepnets within the lake was always $4 \mathrm{~h}$. The hatchery water is untreated water from a nearby stream. Thus, water temperature in the hatchery varies throughout the year along with the variation in natural waters of the area. Water quality of the hatchery water is considered to be good ( $\mathrm{pH}$ 6.0-6.5). Fish kept at the hatchery acted as controls.

\subsection{Experimental protocol}

The study was carried out as 12 separate exposures of fish to the lake water, i.e. one $48 \mathrm{~h}$ exposure each month. We exposed two different year classes (1993 and 1994) monthly in the period from October 1994 to May 1995, and three different year classes (1993, 1994 and 1995) from July 1995 to September 1995 (see Tab. 1). Approximately 30 fish from each year class were placed in the keepnets (150 litre), one keepnet for each year class. The fish density in the keepnets was well below the density of fish in the holding tanks within the hatchery. The keepnets were placed in the middle of the lake, at $2 \mathrm{~m}$ depth. The midwater location was chosen to avoid disturbances of ice, wind, etc. in the littoral zone, and to avoid extreme changes in water chemistry in the surface during the initial snow melt (Johannessen et al. 1980). Mortality was recorded every $4 \mathrm{~h}$, and dead fish were removed from the keepnets. Fish were judged to be dead when opercular movements had ceased and no swimming response could be elicited through stimulation of the lateral line organ. Fish surviving the $48 \mathrm{~h}$ exposures were killed by a blow to the head. Length and weight of all fish were recorded (Tab. 1).

Water samples were collected immediately after the fish exposures, at the same location and depth as the fish were kept. We used a 3 litre Ruttner sampler to collect the water samples. In situ measurements of water temperature and concentrations of dissolved $\mathrm{O}_{2}$ were also carried out. $\mathrm{pH}$ and conductivity measurements, and aluminium fractionation, were performed immediately after arriving in the laboratory, i.e. never later than $4 \mathrm{~h}$ after sampling. The remaining analyses of water chemistry were conducted within a few days after sampling (see Tab. 2).

\subsection{Analytical techniques}

$\mathrm{pH}$ was measured using a Radiometer PHM- 80 with a Radiometer GK-2401C combined glass-electrode. The $\mathrm{pH}$ readings were taken when the $\mathrm{pH}$-meter drifted less 
Tab. 2. Physico-chemical parameters of Lake Nepptjern water during the experimental period $(\mathrm{n}=12)$.

\begin{tabular}{|c|c|c|c|}
\hline & Units & mean \pm s.d. & range \\
\hline Temperature & ${ }^{\circ} \mathrm{C}$ & $7.7 \pm 5.8$ & $1.7-18.9$ \\
\hline Conductivity & $\mu \mathrm{S} \mathrm{cm}^{-1}$ & $22.3 \pm 3.0$ & $19.7-29.2$ \\
\hline Dissolved Oxygen & mg 1-1 & $9.7 \pm 1.0$ & $10.7-7.5$ \\
\hline $\mathrm{pH}$ & & $5.2 \pm 0.2$ & $4.8-5.4$ \\
\hline Alkalinity & $\mu e q 1^{-1}$ & $9.8 \pm 3.4$ & $19.1-7.7$ \\
\hline $\mathrm{Na}^{+}$ & $\mu \mathrm{eq} 1^{-1}$ & $66.9 \pm 12.1$ & $99.2-50.5$ \\
\hline $\mathrm{K}^{+}$ & $\mu e q 1^{-1}$ & $4.6 \pm 1.3$ & $8.4-3.8$ \\
\hline $\mathrm{Ca}^{2+}$ & $\mu$ eq $1^{-1}$ & $45.8 \pm 6.5$ & $53.9-32.9$ \\
\hline $\mathrm{Mg}^{2+}$ & $\mu$ eq $1^{-1}$ & $21.3 \pm 4.1$ & $31.3-15.6$ \\
\hline $\mathrm{Cl}^{-}$ & $\mu e q 1^{-1}$ & $53.1 \pm 13.8$ & $93.1-39.5$ \\
\hline $\mathrm{SO}_{4}{ }^{2-}$ & $\mu$ eq $1^{-1}$ & $104 \pm 6$ & $110-89.5$ \\
\hline $\mathrm{F}^{-}$ & $\mu$ eq $1^{-1}$ & $3.8 \pm 0.7$ & $5.5-3.1$ \\
\hline $\mathrm{NO}_{3}^{-}$ & $\mu \mathrm{eq} \mathrm{l}^{-1}$ & $3.0 \pm 1.1$ & $4.4-1.1$ \\
\hline $\mathrm{NH}_{4}^{+}$ & $\mu e q 1^{-1}$ & $1.0 \pm 0.4$ & $1.6-0.4$ \\
\hline Total nitrogen & $\mu \mathrm{g}^{-1}$ & $196 \pm 87$ & $380-125$ \\
\hline $\mathrm{SiO}_{2}$ & $\mathrm{mg} \mathrm{l}^{-1}$ & $3.6 \pm 0.9$ & $4.3-0.9$ \\
\hline Total organic carbon (TOC) & $\mathrm{mg} \mathrm{l}^{-1}$ & $1.9 \pm 0.4$ & $2.5-1.1$ \\
\hline Total Al $\left(\mathrm{Al}_{\mathrm{r}}\right)$ & $\mu \mathrm{g}^{-1}$ & $404 \pm 62$ & $497-296$ \\
\hline Organic monomeric $\mathrm{Al}\left(\mathrm{Al}_{\mathrm{o}}\right)$ & $\mu g \mathrm{l}^{-1}$ & $52 \pm 14$ & $73-31$ \\
\hline Inorganic monomeric $\mathrm{Al}\left(\mathrm{Al}_{\mathrm{i}}\right)$ & $\mu \mathrm{g} \mathrm{l}^{-1}$ & $283 \pm 51$ & $339-197$ \\
\hline Ionic strength & $\mu \mathrm{M}$ & $260 \pm 33$ & $322-214$ \\
\hline ANC & $\mu \mathrm{eq} \mathrm{l}^{-1}$ & $-22.6 \pm 7.7$ & $-11.4--37.2$ \\
\hline
\end{tabular}

than $0.01 \mathrm{pH}$ unit per minute. The conductivity $\left(\kappa_{25}\right)$ was measured with a Radiometer CDM-80. The conductivity was read when three consecutive measurements were identical within one tenth of a unit. The in situ measurements of water temperature and dissolved $\mathrm{O}_{2}$ were conducted with a YSI-model 5739 Oxymeter.

Aqueous aluminium was fractionated by the HQMIBK extraction technique described by Barnes (1975), combined with the cation exchange procedure described by Driscoll (1984) according to the protocol described by Lydersen et al. (1990a) and Poléo et al. (1997). The aluminium concentrations were measured by a Shimadzu UV-1201 spectrophotometer at $395 \mathrm{~nm}$ (Tikhonov 1973). Absorbance was also measured at $600 \mathrm{~nm}$ in order to correct for iron interference (Sullivan et al. 1986).

Calcium, magnesium, and sodium were analysed by Induced Coupled Plasma atomic-emission spectrometry (ICP), while potassium was analysed by Atomic Absorption flame Spectrophotometry (AAS). Sulphate and chloride were measured by ion chromatography (IC), while total fluoride was analysed according to Harwood (1969) using an Orion Model 94-09 ion selective electrode, connected to an Orion Research Microprocessor Ion Analyser/901 with the Orion Model 90-01-00 as reference electrode. Total nitrogen, nitrate and ammonium was measured colourimetrically. Alkalinity was measured by potentiometric titration with hydrochloric acid to $\mathrm{pH} 4.5$. Total organic carbon (TOC) was measured by a standard combined photochemical (UV) wetchemical $\left(\mathrm{S}_{2} \mathrm{O}_{8}{ }^{2-}\right)$ oxidation method. Silicon was measured spectrophotometrically by the standard molybdateblue complexing method.

\subsection{Calculations and statistics}

The acid neutralising capacity (ANC) was estimated according to Reuss \& Johnson (1986):

$$
\begin{gathered}
\operatorname{ANC}\left(\mu \text { eq } \mathrm{l}^{-1}\right)=\Sigma\left(\left[\mathrm{Ca}^{2+}\right]+\left[\mathrm{Mg}^{2+}\right]+\left[\mathrm{Na}^{+}\right]+\left[\mathrm{K}^{+}\right]\right)- \\
\Sigma\left(\left[\mathrm{SO}_{4}{ }^{2-}\right]+\left[\mathrm{NO}_{3}{ }^{-}\right]+\left[\mathrm{Cl}^{-}\right]\right)
\end{gathered}
$$

The ionic strength (I) was calculated as:

$$
\mathrm{I}=0.5 \Sigma c_{i} z_{i}^{2}
$$

$c_{i}$ is the molar concentration of an ion $\mathrm{i}$ and $z_{i}$ its charge. The sum is taken over all ions in the solution.

Multiple regression analysis was used to test the influence of the various physico-chemical and biological parameters on fish mortality. Cumulative mortality after 24 and $48 \mathrm{~h}$ was the dependent variable in the analysis. We used a backwards stepwise procedure, starting with a full model and manually removing nonsignificant parameters. Akaike Information Criterium (AIC) was employed, and minimised in order to find the optimal model.

\section{RESULTS}

\subsection{Water chemistry}

The physico-chemical properties of the lake varied throughout the year (Tab. 2). The water temperature remained under $5^{\circ} \mathrm{C}$ from October 1994 until the spring 1995. The temperature increased to about $20{ }^{\circ} \mathrm{C}$ in the summer (Fig. 1). pH was low, between 5.0 and 5.5, under the whole experimental period, but dropped to 4.8 during the snow melt in April. There was also a clear 

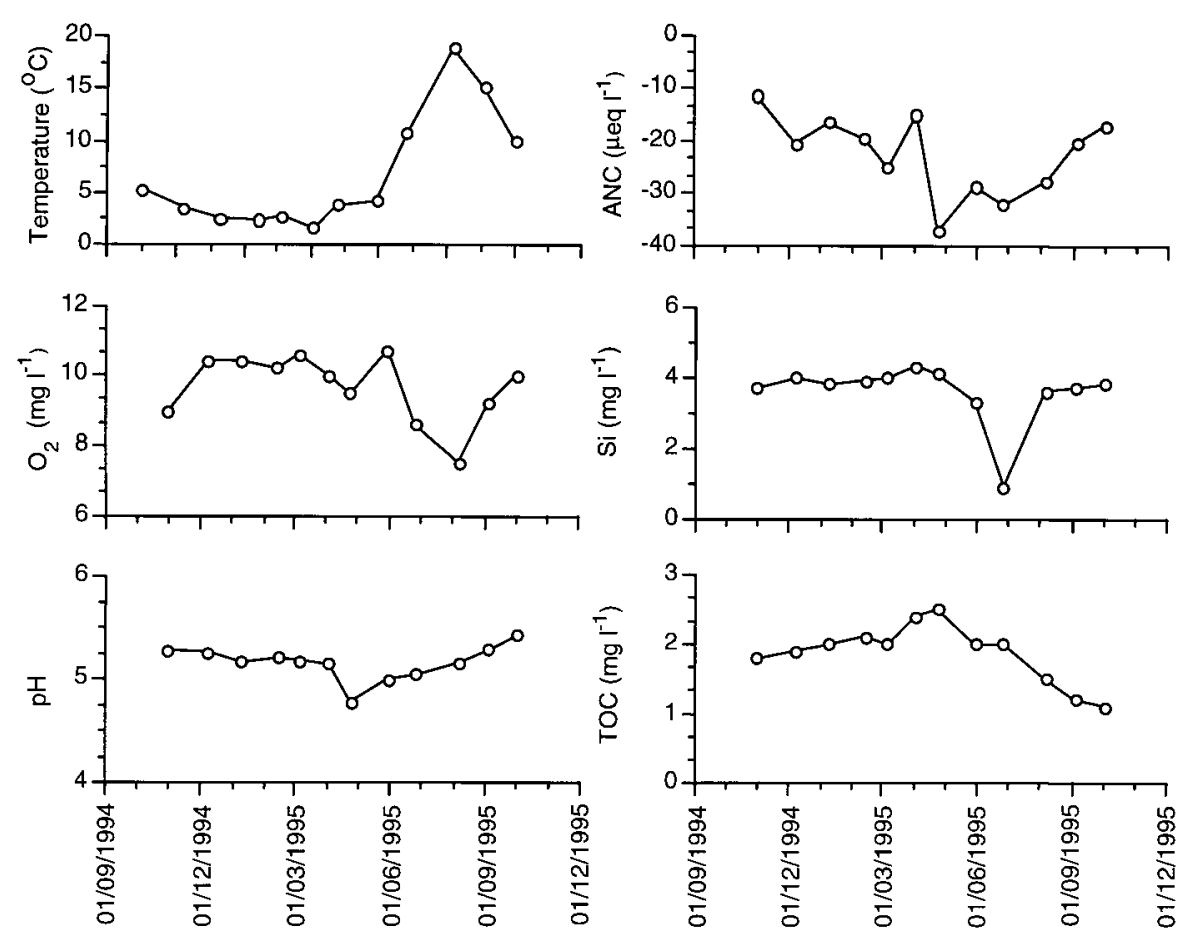

Fig. 1. Seasonal variation in some major physico-chemical water parameters in Lake Nepptjern water at $2 \mathrm{~m}$ depth.

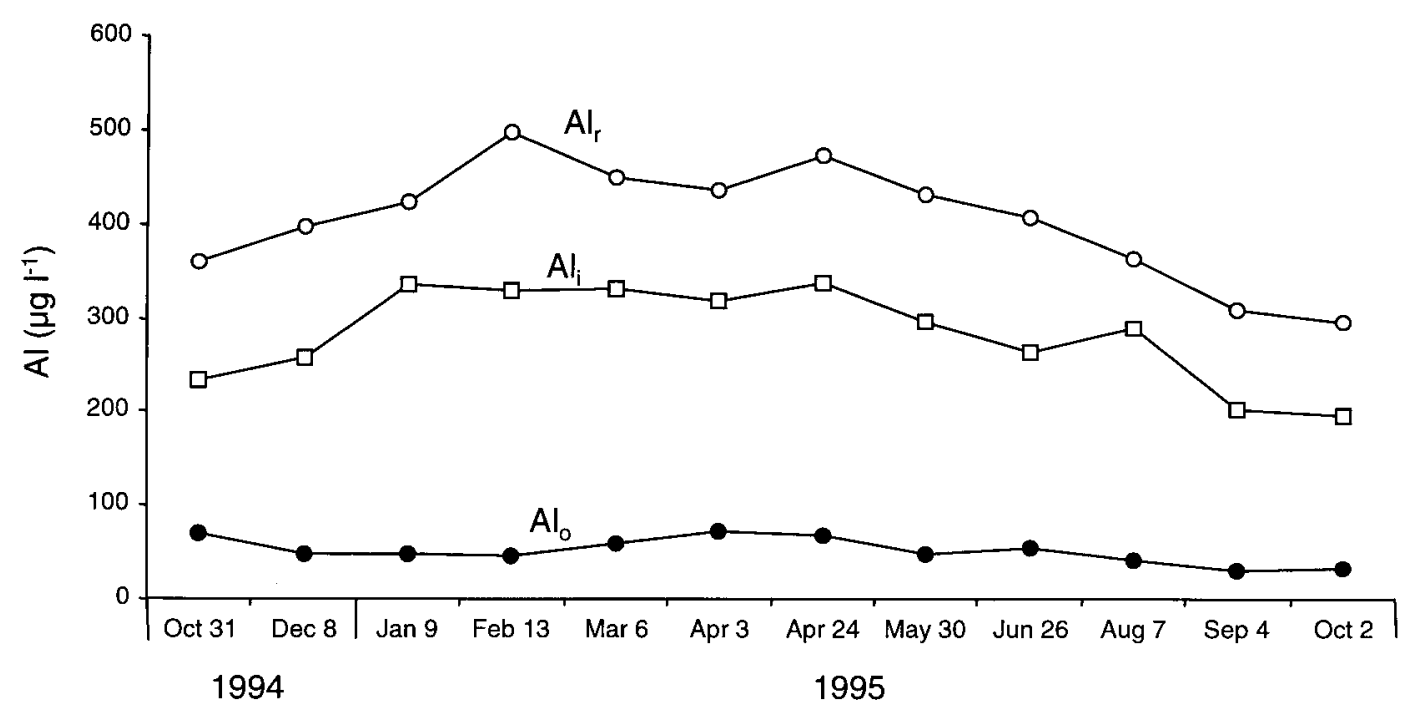

Fig. 2. Seasonal variation in aqueous aluminium in Lake Nepptjern water at $2 \mathrm{~m}$ depth. Total aluminium $\left(\mathrm{Al}_{\mathrm{r}}\right)$, inorganic monomeric aluminium $\left(\mathrm{Al}_{\mathrm{i}}\right)$, and organic monomeric aluminium $\left(\mathrm{Al}_{\mathrm{o}}\right)$.

drop in ANC during snowmelt, from about -20 to -37 $\mu$ eq $\mathrm{l}^{-1}$. There was a gradual increase in TOC from 1.8 $\mathrm{mg} \mathrm{l}^{-1}$ in October 1994 to $2.5 \mathrm{mg} \mathrm{l}^{-1}$ in April 1995, and a decrease during summer, down to $1.1 \mathrm{mg} \mathrm{l}^{-1}$.

The amount of total aluminium $\left(\mathrm{Al}_{\mathrm{r}}\right)$ varied between 300 and $500 \mu \mathrm{g} \mathrm{l}^{-1}$ during the experimental period (Tab. 2 and Fig. 2). The highest concentrations were measured during the winter, i.e. February to May. The concentration of inorganic monomeric aluminium $\left(\mathrm{Al}_{\mathrm{i}}\right)$ was also relatively high (between 200 and $340 \mu \mathrm{g} \mathrm{l}^{-1}$ ), and varied according to the variation in $\mathrm{Al}_{\mathrm{r}}$. $\mathrm{Al}_{\mathrm{i}}$ constituted more than $70 \%$ of the amount of $\mathrm{Al}_{\mathrm{r}}$. The concentration of organic monomeric aluminium $\left(\mathrm{Al}_{\mathrm{o}}\right)$ was low, and varied between 31 and $73 \mu \mathrm{g} \mathrm{l}^{-1}$. 


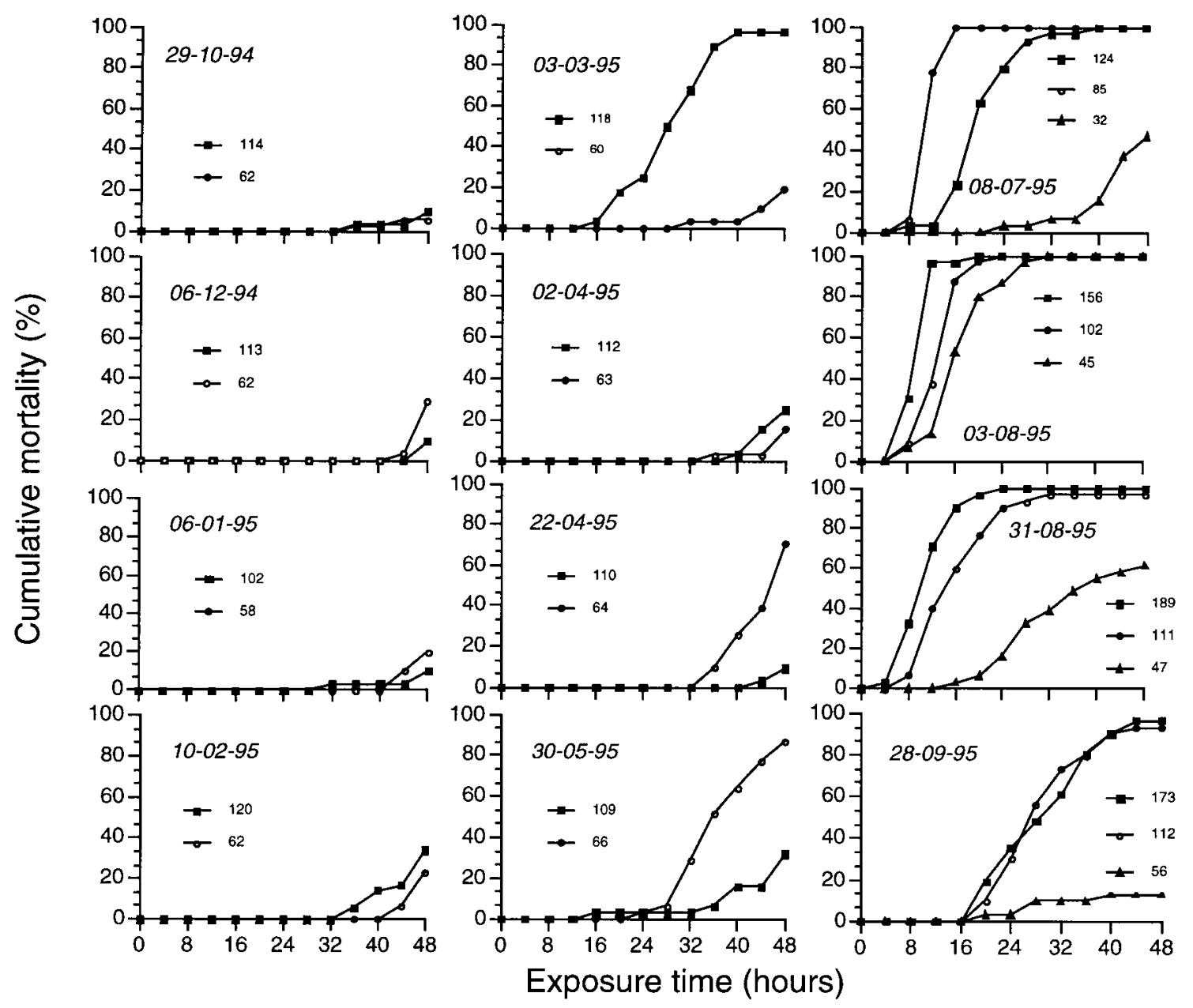

Fig. 3. Seasonal variation in cumulative mortality of different year classes of brown trout exposed to Lake Nepptjern water. The starting date for each experiment, and the mean length of fish used are indicated.

\subsection{Fish mortality}

The mortality data shows that Lake Nepptjern water is highly toxic to brown trout. However, the mortality varied throughout the year, and among year classes, i.e. size groups (Fig. 3). The mortality was relatively low during winter for all size groups. One exception to this was an unexpected high mortality in the largest fish under the March 1995 experiment. We have no reasonable explanation why the mortality was so high in these fish during this experiment. The hatchery from where we obtained the fish reported no irregularities from this period concerning fish quality and health. During spring, April to May, the mortality increased and was highest in the small fish. From July, we also exposed a third group of fish, which were very small (young of the year). The mortality was always lower in these fish compared to the larger size groups. No mortality was observed in the hatchery on the same dates as fish were exposed in Lake Nepptjern.
More than $82 \%$ of the variance in mortality after 24 $\mathrm{h}$ exposure to Lake Nepptjern water, could be explained by the variation in water temperature, fish length, amounts of TOC and silicon (Multiple stepwise regression, Tab. 3). Excluding the unexpected high mortality of large fish in March from the analysis did not influence the results. Water temperature and fish length were the factors which most strongly explained the mortality variation. In general, mortality increased with increasing water temperature and fish length. According to the analysis, the amounts of TOC and silicon seem to be less important for the mortality than water temperature and fish length. However, mortality increased with increasing TOC concentration, and decreased with increasing silicon concentration. After $48 \mathrm{~h}$ exposure, $62 \%$ of the variance in mortality could be explained by the variation in water temperature, ANC and fish length, irrespective of the March-95 mortality (Tab. 3). Water temperature was still the most important factor influencing fish mortality, while fish length and ANC were 
Tab. 3. Results of multiple stepwise regression analysis of mortality at 24 and 48 hours exposures, using fish length and all physico-chemical parameters measured at $2 \mathrm{~m}$ depth as independent variables. The $F$-ratio and $p$-values for each parameter retained in the model are given, together with parameter estimates $( \pm$ s.e. $) .{ }^{1)}$ D.F. $=1$ for all effects

\begin{tabular}{lccc}
\hline Effect & $F^{l)}$ & $p$ & Estimate \\
\hline 24 hour exposure $\left(R^{2}=0.829, n=28, p<0.001\right)$ & & \\
Intercept & & $-74.42 \pm 38.68$ \\
Length & 14.60 & $<0.001$ & $0.36 \pm 0.10$ \\
Temperature & 42.04 & $<0.001$ & $6.31 \pm 0.97$ \\
Silicon & 3.03 & 0.095 & $-7.36 \pm 4.23$ \\
TOC & 3.98 & 0.058 & $25.19 \pm 12.63$ \\
48 hour exposure $\left(R^{2}=0.628, n=28, p<0.001\right)$ & & \\
Intercept & & & $-38.15 \pm 20.26$ \\
Length & 4.81 & 0.038 & $0.28 \pm 0.13$ \\
Temperature & 19.47 & $<0.001$ & $3.81 \pm 0.86$ \\
ANC & 5.56 & 0.027 & $-1.60 \pm 0.68$ \\
\hline
\end{tabular}

less important. Mortality increased with increasing water temperature and fish length, and decreased with increasing ANC.

\section{DISCUSSION}

The acidic aluminium rich Lake Nepptjern water was acutely toxic to brown trout. We have observed that this toxicity varies throughout the year, and that it is primarily dependent on water temperature and fish length. Based on this, we suggest that the degree of hypoxia is important for the mortality variation among experiments and size groups.

The high toxicity of Lake Nepptjern water corresponds well with current knowledge about aluminium toxicity in fish (Howells et al. 1994; Gensemer \& Playle 1999). It is well documented that inorganic monomeric aluminium is important for toxicity of acidic water (Driscoll et al. 1980; Howells et al. 1994; Gensemer \& Playle 1999), and that $\mathrm{Al}_{\mathrm{i}}$-concentrations of more than $50 \mu \mathrm{g}^{-1}$ can be acutely toxic to fish (Fivelstad \& Leivestad 1984). In Lake Nepptjern, the $\mathrm{Al}_{\mathrm{i}}$-concentration was between 200 and $340 \mu \mathrm{g} \mathrm{l}^{-1}$. Earlier toxicity studies using Lake Nepptjern water confirm the high toxicity of the water from this lake (Lydersen et al. 1990b, 1994). However, the intensity of the aluminium toxicity of this water varies depending on different physico-chemical and biological properties.

According to the regression analysis, water temperature is the most important factor for the mortality variation in our study. Poléo et al. (1991) and Poléo \& Muniz (1993) showed that water temperature has a strong impact on aluminium toxicity in fish. They observed that mortality in Atlantic salmon, Salmo salar, increased with increasing temperature. This is in accordance to our present results, and Poléo et al. (1991) and Poléo \& Muniz (1993) explained this temperature dependent toxicity mainly by the influence of temperature on aluminium chemistry. The solubility of $\mathrm{Al}(\mathrm{OH})_{3}(\mathrm{~s})$ and its hydrolysis are highly temperature sensitive
(Lydersen et al. 1990a, 1991), and the distribution of the various dissolved inorganic aluminium species in acidic aluminium rich water vary with temperature (Lydersen 1990; Poléo et al. 1991). On the other hand, it is also reported that aluminium toxicity is mainly dependent on changes in water physico-chemical conditions rather than on the occurrence of a certain toxic aluminium species (Dickson 1978; Grahn 1980; Baker \& Schofield 1982; Rosseland et al. 1992). Based on this, Poléo (1995) proposed that aluminium polymerisation onto the gill surface, in which inorganic monomeric aluminium species act as precursors, is a mechanism that gives a good explanation for the acute toxicity of aluminium in fish. Accordingly, increasing water temperature enhances the aluminium polymerisation process (Lydersen et al. 1990a, 1991).

Through its effect on metabolism water temperature does also affect fish directly, and indirectly by its effect on $\mathrm{O}_{2}$-solubility in water. At high temperature, the metabolism in fish is increased, i.e. higher $\mathrm{O}_{2}$-demand. At the same time, the $\mathrm{O}_{2}$-solubility in water is reduced, i.e. lower $\mathrm{O}_{2}$-availability (see Fig. 1). These effects can also, to some extent, explain why the mortality in the present study increased with increasing temperature. The measured dissolved oxygen of the water decreased to $7.5 \mathrm{mg} \mathrm{l}^{-1}$ in the summer. This amount of dissolved oxygen is normally not associated with hypoxia in fish. A common feature, however, in fish exposed to aqueous aluminium is extensive accumulation of aluminium and mucus on the gill surfaces (see Howells et al. 1994; Gensemer \& Playle 1999). In combination with a lowered dissolved $\mathrm{O}_{2}$-concentration, such accumulation might lead to hypoxia. Accordingly, it has been suggested that hypoxia is of major importance for the acute effect of acidic aluminium rich water, especially under unstable physico-chemical conditions (Neville 1985; Poléo et al. 1994, 1995; Witters et al. 1996; Poléo \& Bjerkely 2000). The idea that hypoxia is of importance, is also indicated by the results showing that the larger 
fish had the higher mortality. Large fish have a lower gill surface area/body weight ratio, and thereby a lower relative maximum oxygen uptake, compared to small fish (Huges 1970, 1984).

Neville (1985) points out that ionoregulatory disturbances rather than hypoxia, is the major factor for the acute effect of acidic aluminium rich water at low $\mathrm{pH}$. During spring, i.e. April to May, we observed that the mortality was highest in the small fish. In this period, $\mathrm{pH}$ was at its lowest (4.8). The fact that small fish were more sensitive than large fish to Lake Nepptjern water when $\mathrm{pH}$ was low, can be explained by ionoregulatory disturbances, according to Neville (1985). Due to their relatively larger gill area, small fish will suffer more from diffusive ion loss compared to large fish if acidic aluminium rich water alters gill permeability properties.

The statistical analysis indicated that the amount of TOC and silicon in the water could explain some of the variation in mortality after $24 \mathrm{~h}$, but seem to be of minor importance compared to water temperature and fish length (Tab. 3). In general, organic compounds are believed to reduce aluminium toxicity by complexing inorganic monomeric aluminium (Baker \& Schofield 1980; Driscoll et al. 1980; Witters et al. 1990). On the contrary, we found that mortality increased marginally with increasing TOC concentration. The amount of TOC in Lake Nepptjern, however, is basically low (range $1.1-2.5 \mathrm{mg} \mathrm{l}^{-1}$ ), and its complexing capacity is far from sufficient to complex the large amount of toxic $\mathrm{Al}_{\mathrm{i}}$. This might explain why a small increase in TOC had no mitigating effect on mortality. An other efficient aluminium complexing agent is silicon, which has been demonstrated to detoxify acidic aluminium rich water (Birchall et al. 1989). We found that the mortality decreased with increasing silicon concentration, thus in accordance to what have previously been reported (Birchall et al. 1989).

ANC has been correlated to fish status (Bulger et al. 1993), and Lien et al. (1996) found that intact brown trout populations in most cases corresponded to ANC values higher than $20 \mu \mathrm{eq} 1^{-1}$. The negative ANC in Lake Nepptjern confirm that this water is highly toxic, and it is to be expected that the toxicity increase with decreasing ANC.

\section{CONCLUSIONS}

The present study confirmed earlier observations that Lake Nepptjern water is highly toxic to fish, and showed that this toxicity varies throughout the year. Our analyses point out water temperature as the most important factor for the mortality variations in the study. This corresponds well to earlier reports pointing out water temperature as an important factor for aqueous aluminium chemistry and acute Al-toxicity in fish. We suggest that the dependence of water $\mathrm{O}_{2}$-solubility and fish metabolism upon temperature is of importance for the temperature-dependent mortality observed. To some extent, this was supported by the higher mortality in large fish than in small fish, due to a lower gill surface area/body weight ratio.

\section{ACKNOWLEDGMENT}

We thank the Norwegian Directorate for Nature Management for funding this project, and Bjørn R. Hansen at the OFA-hatchery for all help with the fish.

\section{REFERENCES}

Baker, J.P. \& C.L. Schofield. 1980. Aluminum toxicity to fish as related to acid precipitation and Adirondack surface water quality. In: D. Drabløs \& A. Tollan (Eds), Ecological impact of acid precipitation. SNSF-project, Sandefjord, Norway: 292-293.

Baker, J.P. \& C.L. Schofield. 1982. Aluminum toxicity to fish in acidic waters. Water Air Soil Pollut., 18: 289-309.

Barnes, R.B. 1975. The determination of specific forms of aluminium in natural water. Chem. Geol., 15: 177-191.

Birchall, J.D., C. Exley, J.S. Chappell \& M.J. Phillips. 1989. Acute toxicity of aluminium to fish eliminated in siliconrich waters. Nature, 338: 146-148.

Bulger, A.J., L. Lien, B.J. Cosby \& A. Henriksen. 1993. Brown trout (Salmo trutta) status and chemistry from the Norwegian Thousand lake Survey: statistical analysis. Can. J. Fish. aquat. Sci., 50: 575-585.

Cronan, C.S. \& C.L. Schofield. 1979. Aluminum leaching response to acid precipitation: Effects on high-elevation watersheds in the Northeast. Science, 204: 304-306.

Dickson, W. 1978. Some effects of the acidification of Swedish lakes. Verh. int. Ver. Limnol., 20: 851-856.

Driscoll, C.T. 1984. A procedure for the fractionation of aqueous aluminium in dilute acidic water. Internat. J. Environ. Analyt. Chem., 16: 267-283.

Driscoll, C.T. \& K.M. Postek. 1996. The chemistry of aluminum in surface waters. In: G. Sposito (Ed.), The Environmental Chemistry of Aluminum ( $2^{\text {nd }}$ ed.). Lewis Publishers, New York: 363-418.

Driscoll, C.T., J.P. Baker, J.J. Bisogni \& C.L. Schofield. 1980. Effects of aluminum speciation on fish in dilute acidified waters. Nature, 284: 161-164.

Fivelstad, S. \& H. Leivestad. 1984. Aluminium toxicity to Atlantic salmon (Salmo salar L.) and brown trout (Salmo trutta L.): mortality and physiological response. Report Inst. Freshw. Res. Drottningholm., 61: 69-77.

Gensemer, R.W. \& R.C. Playle. 1999. The bioavailability and toxicity of aluminum in aquatic environments. Crit. Rev. Environ. Sci. Technol., 29: 315-450.

Grahn, O. 1980. Fishkills in two moderately acid lakes due to high aluminum concentration. In: D. Drabløs \& A. Tollan (Eds), Ecological impact of acid precipitation. SNSFproject, Sandefjord, Norway: 310-311.

Grande, M. 1970. Relationships between dissolved $\mathrm{O}_{2}$, organic matter, $\mathrm{pH}$ and fish production in small lakes. Norwegian Inst. Water Res., Progress Report, B-5/69, Part 1 (In Norwegian).

Harwood, J.E. 1969. The use of an ion-selective electrode for routine fluoride analysis on water samples. Water Res., 3: 273-280.

Henriksen, A. \& S. Andersen. 1992. Acidification status in lakes in the Oslo area. Norwegian Inst. Water Res., Acid Rain Res. Report, 2/1992, F-80408 (in Norwegian).

Howells, G., T.R.K. Dalziel, J.P. Reader \& J.F. Solbe. 1994. Aluminium and freshwater fish water quality criteria. In: G. Howells (Ed.), Water quality for freshwater fish. Gordon and Breach Sci. Publ., England: 55-115.

Hughes, G.M. 1970. Morphological measurements on the gills of fishes in relation to their respiratory function. Folia Morphol., 18: 78-95. 
Hughes, G.M. 1984. General anatomy of the gills; VI Gill morphometry. In: W.F. Hoar \& D.J. Randall (Eds), Fish physiology (Vol. X), Academic Press, Orlando, US: 40-63.

Johannessen, M., A. Skartveit \& R.F. Wright. 1980. Streamwater chemistry before, during and after snowmelt. In: D. Drabløs \& A. Tollan (Eds), Ecological impact of acid precipitation. SNSF-project, Sandefjord, Norway: 224-225.

Lien, L., G.G. Raddum, A. Fjellheim \& A. Henriksen. 1996. A critical limit for acid neutralising capacity in Norwegian surface waters, based on new analyses of fish and invertebrate responses. Sci. Total Environ., 177: 173-193.

Lydersen, E. 1990. The solubility and hydrolysis of aqueous aluminium hydroxides in dilute fresh waters at different temperatures. Nordic Hydrol., 21: 195-204.

Lydersen, E., B. Salbu \& A.B.S. Poléo. 1991. Formation and dissolution kinetics of $\mathrm{Al}(\mathrm{OH})_{3}$ (s) in synthetic freshwater solutions. Water Resour. Res., 27: 351-357.

Lydersen, E., B. Salbu, A.B.S. Poléo \& I.P. Muniz. 1990a The influences of temperature on aqueous aluminium chemistry. Water Air Soil Pollut., 51: 203-215.

Lydersen, E., A.B.S. Poléo, I.P. Muniz, B. Salbu \& H.E. Bjørnstad. 1990b. The effect of naturally occurring high and low molecular weight inorganic and organic species on the yolk-sack larvae of Atlantic salmon (Salmo salar L.) exposed to acidic aluminium-rich water. Aquat. Toxicol., 18: 219-230.

Lydersen, E., A.B.S. Poléo, M. Nandrup-Pettersen, G. Riise, B. Salbu, F. Kroglund \& B.O. Rosseland. 1994. The importance of in situ measurements to relate toxicity and chemistry in dynamic aluminium freshwater systems. $J$. Ecol. Chem., 3: 357-365.

McDonald, D.G. 1983. The effects of $\mathrm{H}^{+}$upon the gills of freshwater fish. Can. J. Zool., 61: 691-703.

Neville, C.M. 1985. Physiological responses of juvenile rainbow trout, Salmo gairdneri, to acid and aluminum - Prediction of field responses from laboratory data. Can. J. Fish. aquat. Sci., 42: 2004-2019.

Poléo, A.B.S. 1995. Aluminium polymerisation - a mechanism of acute toxicity of aqueous aluminium to fish. Aquat. Toxicol., 31: 347-356.

Poléo, A.B.S. \& F. Bjerkely. 2000. Effect of unstable aluminium chemistry on Arctic char (Salvelinus alpinus). Can. J. Fish. aquat. Sci., 57: 1423-1433.

Poléo, A.B.S. \& I.P. Muniz. 1993. The effect of aluminium in soft water at low $\mathrm{pH}$ and different temperatures on mortality, ventilation frequency and water balance in smoltifying Atlantic salmon, Salmon salar. Environ. Biol. Fish., 36: 193-203.

Received: May 2001

Accepted: February 2002
Poléo, A.B.S., E. Lydersen \& I.P. Muniz. 1991. The influence of temperature on aqueous aluminium chemistry and survival of Atlantic salmon (Salmo salar L.) fingerlings. Aquat. Toxicol., 21: 267-278.

Poléo, A.B.S., K. Østbye, S.A. Øxnevad, R.A. Andersen, E. Heibo \& L.A. Vøllestad. 1997. Toxicity of acid aluminium-rich water to seven freshwater fish species: A comparative laboratory study. Environ. Pollut., 96: 129-139.

Poléo, A.B.S., S.A. Øxnevad, K. Østbye, R.A. Andersen, D.H. Oughton \& L.A. Vøllestad. 1995. Survival of crucian carp, Carassius carassius, exposed to a high low-molecular weight inorganic aluminium challenge. Aquat. Sci., 57: 350-359.

Poléo, A.B.S., E. Lydersen, B.O. Rosseland, F. Kroglund, B. Salbu, R.D. Vogt \& A. Kvellestad. 1994. Increased mortality of fish due to changing Al-chemistry of mixing zones between limed streams and acidic tributaries. Water Air Soil Pollut., 75: 339-351.

Reuss, J.O. \& D.W. Johnson. 1986. Acid deposition and the acidification of soils and waters. Ecological Studies (Vol. 59), Springer-Verlag, New York: 119 pp.

Rosseland, B.O., I.A. Blakar, A. Bulger, F. Kroglund, A. Kvellestad, E. Lydersen, D.H. Ougthon, B. Salbu, M. Staurnes \& R.D. Vogt. 1992. The mixing zone between limed and acidic river waters: complex aluminium chemistry and extreme toxicity for salmonids. Environ. Pollut., 78: 3-8.

Sullivan, T.J., H.M. Seip \& I.P. Muniz. 1986. A comparison of frequently used methods for the determination of aqueous aluminium. Internat. J. Environ. Anal. Chem., 26: 6175.

Sparling, D.W. \& T.P. Lowe. 1996. Environmental hazards of aluminum to plants, invertebrates, fish, and wildlife. Rev. Environ. Contam. Toxicol., 145: 1-127.

Tikhonov, V.N. 1973. Analytical chemistry of aluminium. John Wiley and Sons, New York: 303 pp.

Witters, H.E., S. Van Puymbroeck, A.J.H.X. Stouthart \& S.E. Wendelaar Bonga. 1996. Physico-chemical changes of aluminium in mixing zones: Mortality and physiological disturbances in brown trout (Salmo trutta L.). Environ. Toxicol. Chem., 15: 986-996.

Witters, H.E., S. Van Puymbroeck, J.H.D. Vangenechten \& O.L.J. Vanderborght. 1990. The effect of humic substances on the toxicity of aluminium to adult rainbow trout, Oncorhynchus mykiss (Walbaum). J. Fish Biol., 37: 43-53.

Wood, C.M. \& D.G. McDonald. 1987. The physiology of acid/aluminium stress in fish. Annal. Soc. R. Zool. Belg., 117, Suppl. 1: 339-410. 